\title{
SEJARAH, UNSUR KEBUDAYAAN, DAN NILAI PENDIDIKAN KARAKTER DALAM LEGENDA SUNGAI NAGA
}

\author{
Suwarno, Kundharu Saddhono, dan Nugraheni Eko Wardani \\ Program Studi Magister Pendidikan Bahasa Indonesia, Universitas Sebelas Maret \\ Jalan Ir. Sutami 36A, Kentingan, Jebres, Surakarta, Indonesia \\ Surel: warnobm@gmail.com
}

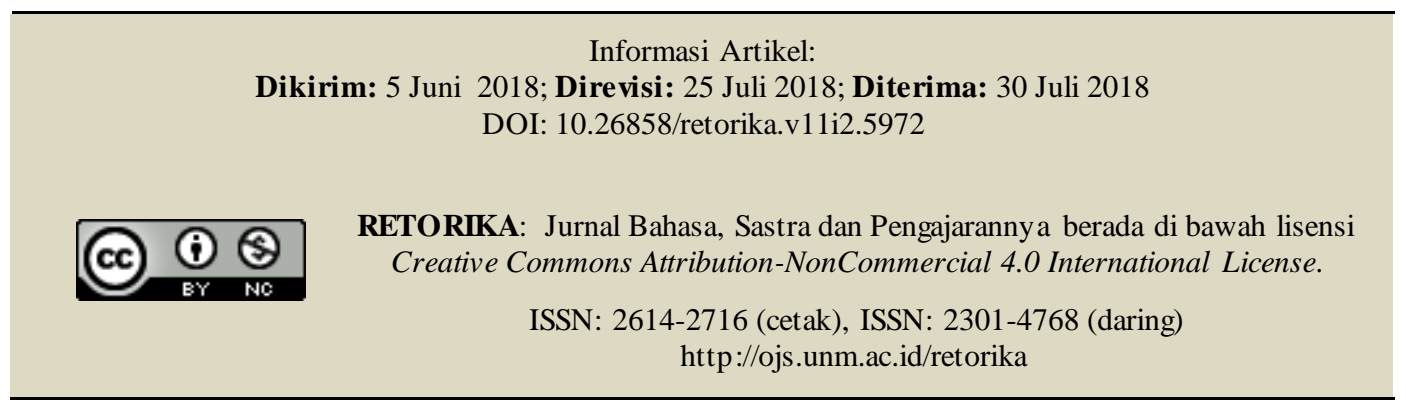

\begin{abstract}
History, Cultural Elements, and the Value of Character Education in the Legenda Sungai Naga. The purpose of this study is to describe the history, elements of culture, and the value of character education on the Legenda Sungai Naga. Data collection through interviews, documentation, and observation. Data analysis technique used qualitative analysis of inductive model with purposive sampling technique. The results obtained that the name of the Dragon River taken based on the history of Gerdu figures that dispels the Dragon Snake that pass in the river. It found three elements of culture that is naming places, namely knowledge system, living equip ment system and technology, and religious system. There are three values of character education that is the value of hard work character, religious character value, and value of environmental caring character.
\end{abstract}

\begin{abstract}
Abstrak: Sejarah, Unsur Kebudayaan, dan Nilai Pendidikan Karakter dalam Legenda Sungai Naga. Tujuan penelitian ini adalah mendeskripsikan sejarah, unsur kebudayaan, dan nilai pendidikan karakter pada legenda Sungai Naga. Pengumpulan data melalui wawancara, dokumentasi, dan observasi. Teknik analis is data menggunakan analisis kualitatif model induktif. Hasil penelitian menunjukkan bahwa nama Sungai Naga diambil berdasarkan sejarah tokoh Gerdu yang menghalau terjangan Ular Naga yang melintas di sungai tersebut. Ditemukan tiga unsur kebudayaan, yaitu sistem pengetahuan, sistem peralatan hidup dan teknologi, dan sistem religi. Terdapat tiga nilai pendidikan karakter, yaitu nilai karakter kerja keras, nilai karakter religius, dan nilai karakter peduli lingkungan.
\end{abstract}

Kata kunci: kebudayaan, karakter, legenda, Sungai Naga, Ngawi 
Legenda Sungai Naga merupakan sebuah legenda yang ada di Kabupaten Ngawi, Jawa Timur. Objek yang menjadi asal-usul Legenda Sungai Naga adalah sungai yang ada di Dusun Ngadiluwih yang merupakan aliran sungai dari Gunung Lawu. Legenda Sungai Naga berkisah tentang adanya ular besar yang turun dari Gunung Lawu. Masyarakat menyebut ular besar itu dengan nama Baru Klinting yang merupakan jenis ular naga. Ular tersebut dapat mengakibatkan bencana jika melewati aliran sungai yang ada di Ngadiluwih. Dalam cerita, dikisahkan ada seorang pemuda sakti bernama Gerdu yang berhasil melindungi desanya dari terjangan ular besar tersebut dengan Tongkat Sakti yang ditancapkan di dekat sungai. Setelah ular besar tersebut melewati sungai di Ngadiluwih, di dekat Tongkat Sakti muncul mata air. Cerita ini kemudian menjadi legenda bagi masyarakat setempat.

Penelitian Legenda Sungai Naga sangat penting sebagai bentuk pendokumentasian cerita rakyat lisan yang dapat dimanfaatkan oleh berbagai pihak, khususnya di dunia pendidikan. Dalam Kurikulum 2013, mata pelajaran Bahasa Indonesia jenjang SD, SLTP, dan SLTA terdapat kompetensi dasar tentang legenda dan cerita rakyat. Pada jenjang SD kelas VI terdapat kompetensi dasar menelusuri tuturan dan tindakan tokoh serta penceritaan penulis dalam teks fiksi. Legenda Sungai Naga merupakan bentuk cerita fiksi yang memuat sejumlah perilaku dan tindakan tokohnya. Pada jenjang SLTP kelas VII terdapat kompetensi dasar tentang menggali legenda dari daerah setempat, yakni mengidentifikasi informasi tentang fabel/legenda daerah setempat yang dibaca dan didengar, mene laah struktur dan kebahasan fabel/legenda daerah setempat yang dibaca dan didengar, menceritakan kembali isi cerita fabel/legenda daerah setempat yang dibaca dan didengar, dan memerankan isi fabel/legenda daerah setempat yang dibaca dan didengar. Pada jenjang SLTA kelas X terdapat kompetensi dasar membandingkan nilai-nilai dan kebahasaan cerita rakyat dan cerpen (Permendikbud No. 24 Tahun 2016 Lampiran 1-3).

Ada beberapa alasan yang menjadi dasar pengkajian sejarah, unsur kebudayaan, dan nilai pendidikan karakter dalam Legenda Sungai Naga. Alasan pengkajian aspek sejarah, yakni bahwa nama sebuah tempat merupakan identitas tempat tersebut berada yang memili- ki sejarah dalam penciptaannya. Cerita dalam penciptaan nama tersebut dapat dipengaruhi oleh unsur geografi, budaya, bahasa, dan pikiran yang ada dalam lingkungan tempat tersebut berada. Sebagaimana Rais, dkk. (2008:4) menyatakan bahwa tiap unsur di muka bumi yang disebut unsur geografi atau unsur rupabumi, seperti gunung, bukit, sungai, tanjung, lembah, selat, pulau, dan sebagainya diberi nama oleh manusia sejak manusia ingin mengidentifikasi lingkungan fisiknya di muka bumi untuk tujuan komunikasi atau untuk acuan dengan menunjuk suatu objek geografis tertentu dalam orientasi dirinya terhadap lingkungan fisiknya. Hipotesis Sapir-Worf (dalam Kramsch, 2001:11) menyatakan bahwa penggunaan bahasa memengaruhi cara seseorang berpikir dan berperilaku. Selanjutnya, alasan pengkajian unsur kebudayaan dalam Legenda Sungai Naga dikarenakan sebuah cerita rakyat (legenda) dipengaruhi oleh adat istiadat dan kebudayaan tempat legenda tersebut berada. Suatu legenda tidak lepas dari kebudayaan yang ada. Cerita rakyat (legenda) selain berisi sejarah yang mengandung unsur kebudayaan juga memiliki nilai filosofi, yakni nilai-nilai pendidikan karakter yang mengandung amanat tertentu yang diwariskan dari generasi ke generasi untuk tujuan tertentu.

Kearifan lokal yang ada di Kabupaten Ngawi patut untuk diangkat dan ditunjukkan ke dunia luar. Cerita rakyat dan kearifan lokal perlu dikenalkan dalam dunia pendidikan seiring berlakunya Kurikulum 2013 pada mata pelajaran Bahasa Indonesia. Oleh karena itu, perlu penggalian kearifan-kearifan lokal yang dapat dijadikan materi ajar. Sela in itu, Perpustakaan Daerah Ngawi juga sangat minim referensi yang berkaitan sejarah penamaan tempat di daerahnya. Dengan demikian, hasil penelitian ini dapat menjadi referensi pendidikan karakter.

Penelitian mengenai legenda yang menjadi penamaan tempat telah dilakukanoleh Mardiana (2013), Camalia (2015), dan Azhar (2016). Mardiana menitikberatkan keterkaitan antara bahasa, budaya, dan pikiran manusia dalam proses penamaan tempat-tempat di Mojokerto. Camalia menitikberatkan penemuan struktur tanda dan toponimi Kabupaten Lamongan. Azhar menitikberatkan penelitiannya pada cerita rakyat Bangkalan dan unsur pembentuknya. Dalam penelitian ini dikaji mengenai asal-usul atau sejarah, unsur kebudayaan 
yang ada dalam cerita, dan nilai-nilai pendidikan karakter yang ada dalam Legenda Sungai Naga.

Penelitian mengenai mitos Naga pernah dilakukan di mancanegara. Di Korea, cerita Naga telah menjadi penamaan air terjun, Nine Dragons Waterfall; simbol dari raja dan kekuatannya, Kyungbok Palace; simbol spiritual/re ligius, temple, film, D-War 2007, dan sebagai tafsir mimpi (Lee, 2013). Berbeda dengan penelitian tersebut, kajian legenda Sungai Naga menggunakan perspektif berbeda, yakni latar belakang budaya tempat tumbuh kembangnya mitos, yakni budaya Jawa.

Unsur kebudayaan merupakan bagian dari suatu kebudayaan yang dapat digunakan sebagai analis is. Menurut Koentjaraningrat (2015:156), kebudayaan terbagi ke dalam tujuh unsur, yakni bahasa, sistem pengetahuan, organisasi sosial, sistem peralatan hidup dan teknologi, sistem mata pencaharian hidup, sistem religi, dan kesenian. Berdasarkan ketujuh unsur tersebut, dapat diklasifikasikan menjadi tiga wujud kebudayaan, yaitu wujud kebudayaan sebagai suatu kompleks dari ide-ide gagasan, nilai-nilai, norma-norma, peraturan, dan sebagainya; wujud kebudayaan sebagai suatu kompleks aktivitas serta tindakan berpola dari manusia dalam masyarakat; dan wujud kebudayaan sebagai benda-benda hasil karya manusia.

Cerita rakyat dapat diartikan sebagai ekspresi budaya suatu masyarakat melalui bahasa tutur yang berhubungan langsung dengan berbagai aspek budaya dan susunan nilai sosial masyarakat tersebut. Cerita rakyat yang sesungguhnya bagian dari folklor merupakan salah satu sastra lisan yang berkaitan dengan lingkungan, baik lingkungan masyarakat maupun alam (Musfiroh, 2008:69). Melalui cerita rakyat, konsep penamaan nama tempat muncul. Pemunculan nama tempat tersebut dapat dihasilkan dari nama tokoh, isi peristiwa, maupun bahasa yang ada. Nama-nama yang dihasilkan bergantung pada masyarakat tersebut tinggal dalam berpikir dan berperilaku.

Cerita rakyat yang melatarbelakangi munculnya penamaan suatu tempat termasuk dalam kategori legenda. Legenda adalah dongeng yang berhubungan dengan peristiwa sejarah atau kejadian alam yang bercampur dengan unsur-unsur fantasi, seperti terjadinya nama suatu tempat dan bentuk topografi suatu daerah (Sugiarto, 2015:171-172). Cerita yang berhubungan dengan suatu tempat, nama tempat, dan bentuk topografi tergolong dalam jenis legenda setempat (Danandjaja, 2013:75). Senada dengan itu, Nurgiyantoro (2013:185) menyatakan bahwa cerita yang berkaitan dengan adanya peninggalan tertentu dan atau asal-usul terjadinya sesuatu dan penamaan tempat tertentu disebut legenda tempat.

Legenda yang baik untuk bacaan di sekolah haruslah memiliki nilai-nilai karakter seiring wacana pemerintah yang mendengungkan program pendidikan karakter. Pendidikan karakter adalah upaya sadar dan sungguhsungguh dari seorang guru untuk mengerjakan nilai-nilai kepada para siswanya (Samani dan Hariyanto, 2013:45). Pendidikan karakter adalah sebuah usaha untuk mendidik anak-anak agar dapat mengambil keputusan dengan bijak dan mempraktikannya dalam kehidupan sehari-hari (Kesuma, 2011:5). Jadi, pendidikan karakter adalah usaha untuk mendidik anakanak dengan sungguh-sungguh melalui penanaman nilai-nilai karakter, agar anak-anak dapat mengambil keputusan dengan bijak dan mempraktikannya dalam kehidupan sehari-hari melalui hati, pikir, raga, rasa, dan karsa sebagai anggota masyarakat dan warga negara yang religius, nasionalis, produktif, dan kreatif. Kementerian Pendidikan dan Kebudayaan telah mentapkan nilai karakter dalam dunia pendidikant, yaitu (1) religius, (2) jujur, (3) toleransi, (4) disiplin, (5) kerja keras, (6) kreatif, (7) mandiri, (8) demokratis, (9) rasa ingin tahu, (10) seangat kebangsaan atau nasionalisme, (11) cinta tanah air, (12) menghargai prestasi, (13) komunikatif, (14) cinta damai, (15) gemar membaca, (16) peduli lingkungan, (17) peduli sosial, dan (18) tanggung jawab (Kemendiknas, 2011:8).

Studi ini mengkaji sejarah penamaan, unsur kebudayaan, dan nilai pendidikan karakter pada legenda Sungai Naga di Ngadiluwih, Ngawi. Hasil penelitian diharapkan dapat dimanfaatkan untuk menunjang pembelajaran bahasa Indonesia di jenjang sekolah dasar dan menengah.

\section{METODE}

Jenis penelitian ini adalah penelitian deskriptif dengan pendekatan kualitatif. Menurut Sugiyono (2010:1), metode penelitian 
kualitatif adalah metode penelitian yang digunakan untuk meneliti pada kondisi objek yang alamiah. Pengumpulan data dilakukan melalui wawancara, dokumentasi, dan observasi. Teknik pengambilan sampel yang digunakan adalah teknik purposive sampling (sampel bertujuan), yakni teknik penentuan sampel penelitian dengan pertimbangan tertentu yang bertujuan agar data yang diperoleh bisa lebih representatif.

Instrumen dalam penelitian ini, yaitu human instrumen atau peneliti itu sendiri. Peneliti terlibat langsung dalam mengumpulkan data. Dalam pengumpulan data, peneliti menggunakan alat-alat untuk membantu peneliti dalam mengumpulkan data, seperti (1) alat perekam (tape recorder), (2) handycame, peralatan tulis, dan (3) daftar pedoman wawancara. Data dikumpulkan melalui teknik observasi, wawancara, dan merekam data yang disampaikan oleh informan.

Wawancara dilakukan dengan (1) Patmo dengan alamat Ngadiluwih RT 01/RW02, Desa Wonosari, Kecamatan Sine; (2) Pujo dengan alamat Ngadiluw ih RT 02/RW02, Desa Wonosari, Kecamatan Sine; (3) Harto dengan alamat Pandan RT 03/RW01, Desa Pandansari, Kecamatan Sine. Ketiga informan tersebut merupakan sesepuh dan tokoh masyarakat yang mengetahui sejarah atau informasi yang dibutuhkan terkait Legenda Sungai Naga. Patmo merupakan sesepuh di Ngadiluwih yang sekaligus menjadi juru kunci.

Data yang terkumpul dianalisis menggunakan analisis kualitatif model induktif. Teknik analisis data penelitian dilakukan mela-lui tahapan, yakni (1) mentranskripsikan data hasil rekaman ke dalam bentuk bahasa tulis, (2) menerjemahkan data berbahasa Jawa ke dalam bahasa Indonesia, (3) mendeskripsikan dan menganalis is data untuk menemukan sejarah, unsur kebudayaan, dan nilai-nilai pendidikan karakter dalam Legenda Sungai Naga berdasarkan teori-teori yang relevan, dan (4) menulis simpulan berdasarkan hasil penelitian.

\section{HASIL DAN PEMBAHASAN}

\section{Hasil}

Hasil penelitian dikelompokkan menjadi tiga bagian, yakni sejarah, unsur kebudayaan, dan nilai pendidikan karakter dalam le- genda Sungai Naga. Temuan penelitian diuraikan sebagai berikut.

\section{Se jarah Sungai Naga}

Sungai Naga merupakan sebuah sungai yang menjadi batas antara Provinsi Jawa Timur dan Jawa Tengah, tepatnya batas wilayah antara Kabupaten Ngawi dengan Kabupaten Karanganyar dan Kabupaten Ngawi dengan Kabupaten Sragen. Sungai ini terletak di ujung barat Kabupaten Ngawi. Aliran air Sungai Naga berasal dari Gunung Lawu. Letak Gunung Lawu berada di dua provinsi, yaitu Jawa Tengah dan Jawa Timur. Air dari Gunung Lawu tersebut mengalir hingga ke Bengawan Solo.

Sejarah nama Sungai Naga berhubungan dengan adanya mitos Ular Naga dan Gunung Lawu. Ular Naga yang bersemayam di Gunung Lawu turun menuju ke laut. Perjalanan Naga tersebut akan membawa malapetaka bagi penduduk di sekitar sungai dan daerah yang dilaluinya. Hal tersebut sebagaimana hasil wawancara dengan narasumber berikut.

(1) Sak ngisare seng disukani teken niku tukul sumbere, mulane dijenengne Sumber Naga. Niku asale geh Naga Baru Klinting seng arep lewat Ngadiluwih niku (Sumber: Patmo).

(Di bawah penancapan tongkat itu muncul mata air, sehingga dinamakan Sumber Naga. Itu asalnya dari Naga Baru Klinting yang akan lewat Ngadi-luwih).

(2) .... sak ngandape griyane Mbah Gerdu nanging rodok menceng ngalor ngulon niku uwoh sumber e trus teng Mbah Gerdu dijenengke Sumber Kali Naga (Sumber: Pujo).

(... sebelah utara rumah Mbah Gerdu muncul mata air. Lalu Mbah Ger-du memberi nama mata air Sungai Naga).

(3) Naga niku ajeng lewat, lajeng bar niku disebut e Kali Naga (Sumber: Harto).

(Naga itu akan melintas, setelahnya disebut Sungai Naga).

Berdasarkan hasil wawancara dari ketiga narasumber yang ditunjukkan pada data (1), (2), dan (3), tempat tersebut dinamakan Sungai Naga karena munculnya mata air di tempat penancapan tongkat milik Gerdu yang digunakan sebagai benteng pertahanan untuk 
menghalau terjangan Ular Naga yang melintas di sungai. Dikarenakan mata air tersebut mengalir mengikuti arus sungai sehingga sungai yang dilaluinya dinamakan Sungai Naga.

Tokoh utama dalam Legenda Sungai Naga, yakni seorang pemuda yang memiliki kesaktian, dia bernama Gerdu. Sang Pemuda mencari cara untuk mengatasi bahaya yang aka-n menimpanya. Akhirnya, dia bertapa dan mendapatkan pusaka untuk menyelamatkan desanya yaitu Tongkat Sakti yang diambil dari mata air Serdudo. Setelah hari demi hari, akhirnya ular yang ditunggu pun melintas. Dia menancapkan Tongkat Sakti di pinggir sungai. Tongkat Sakti dapat menghalau terjangan ular besar yang melintas dari Gunung Lawu. Tempat ditancapkannya Tongkat Sakti dapat mengluarkan mata air dan tongkat tersebut tumbuh menjadi pohon besar, yang disebut warga sebagai Pohon Preh. Berdasarkan kisah itu, mata air dan sungai yang dilalui oleh ular besar dinamakan Sungai Naga.

Sejarah Sungai Naga tersebut memiliki kaitan erat dengan tempat-tempat di sekitarnya. Tempat-tempat tersebut yang dijadikan Gerdu sebagai olah ritual sebelum datangnya Ular Naga dari Gunung Lawu. Pertama, Gua Singo Barong yang dijadikan tempat pertapaannya untuk menemukan solusi dalam mengatasi musibah yang akan menimpa desanya. Kedua, mata air Serdudo merupakan tempat pengambilan Tongkat Sakti yang akan dijadikan sebagai benteng pertahanan oleh Gerdu. Ketiga, Sungai Timun dan Sungai Seranti merupakan tempat untuk merendam Tongkat Sakti setelah didapat dari mata air Serdudo.

\section{Unsur Ke budayaan}

Ditemukan tiga unsur kebudayaan dalam Legenda Sungai Naga. Ketiga unsur kebudayaan yang ditemukan, yaitu sistem pengetahuan, sistem peralatan hidup dan teknologi, dan sistem religi.

\section{Sistem Pengetahuan}

Pengetahuan dapat diperoleh dari kejadian yang dialami lewat pancaindra. Lewat pancaindra ditemukan bahwa pengetahuan, pengalaman, dan wawasan suatu masyarakat terbentuk menjadi pola pikir. Kejadian yang dialami masyarakat dalam Legenda Sungai
Naga dapat ditemukan dalam kutipan berikut ini.

(4) "Akhirnya, muncullah mata air di tempat Tongkat Sakti itu tertancap. Oleh karena itu, tempat tersebut diberikan nama Sumber Naga dan memberikan nama sungai yang dilewatinya dengan nama Sungai Naga karena diketahui ular besar tersebut jenis Ular Naga dengan nama Baru Klinting."

Berdasarkan kutipan (4), dapat diketahui pola pikir dan pengetahuan masyarakat untuk memberikan nama pada suatu tempat berdasarkan kejadian yang dialaminya. Diawali adanya Ular Naga yang melintas di sungai, mereka memberikan nama atau menyebut sungai tersebut menjadi Sungai Naga.

(5) Gua Singo Barong terletak di Segandul, Ngadiluwih. Gua ini memiliki lubang yang cukup kecil dan hanya bisa dimasuki oleh orang yang mempunyai kekuatan sakti.

(6) .... Tongkat itu diletakkan di dalam peti dan ditutupi kain putih dengan bunga tujuh rupa serta wewangian

Kutipan (5) dan (6) memperlihatkan bahwa masyarakat telah memiliki pengetahuan untuk keberlangsungan hidupnya. Sebagaimana terlihat telah adanya goa, peti, dan kain. Masyarakat dapat berpikir, menghasilkan ide dan membuat suatu barang. Sebagai contoh, pembuatan peti dan kain, masyarakat telah memiliki ide/gagasan untuk membuatnya, dilanjutkan bahan baku yang digunakan, dan proses pembuatannya yang membutuhkan keterampilan.

\section{Sistem Peralatan Hidup dan Teknologi}

Setiap suku memiliki peralatan dan teknologi yang digunakan dalam kehidupan sehari-hari. Peralatan dan teknologi tersebut sangat berkaitan dengan alam, tingkat pengetahuan/pendidikan, dan perkembangan zaman sehingga setiap suku yang ada di Indonesia memiliki ciri khas.

Sistem tersebut juga terdapat dalam Legenda Sungai Naga, seperti ditunjukkan pada kutipan data (7). 
(7) .... Benteng pertahanan tersebut dibuat dari sebuah tongkat yang diisi kesaktian olehnya. Dia harus menancapkan tongkat sakti tersebut di pinggir sungai yang akan dile wati u lar dari gunung. Tongkat itu harus diambil di dekat mata air Serdudo. Mata air ini tak pernah kering wa laupun di musim kemarau yang lama.

Berdasarkan kutipan (7), dapat diperoleh data bahwa tongkat merupakan alat yang dapat digunakan dalam bertahan hidup. Tongkat tersebut mempunyai kesaktian yang dapat digunakan sebagai benteng pertahanan dari terjangan bahaya.

Selain tongkat, juga ditemukan sistem peralatan hidup pada Legenda Sungai Naga, yaitu sebuah peti. Hal tersebut dapat dilihat pada kutipan (8) di bawah ini.

(8) Selesai dari pertapaannya, Gerdu pulang ke rumah dan menyimpan Tongkat Sakti sebelum direndam di Tempuran. Tongkat itu diletakkan di dalam peti dan ditutupi kain putih dengan bunga tujuh rupa serta wewangian.

Peti dalam Legenda Sungai Naga seperti ditunjukkan pada kutipan (8) merupakan sebuah wadah kecil yang digunakan oleh masyarakat untuk menyimpan barang-barang pusaka/keramat. Terbuat dari kayu yang berbentuk balok dengan hiasan/ukiran di bagian luarnya. Sementara itu, kain putih merupakan kain mori yang biasa digunakan untuk mengkafani jenazah. Peti ini memiliki fungsi bagi masyarakat, di antaranya tempat penyimpanan barang berharga.

\section{Sistem Religi}

Keagamaan dan kepercayaan sangat melekat pada kebudayaan Jawa. Orang Jawa meyakini bahwa selain yang ada dalam dunia nyata juga ada hal-hal gaib yang tidak kasat mata. Masyarakat Jawa dalam melakukan kegiatan sering berpedoman pada hitungan Jawa dan ritual yang membutuhkan kemenyan dan sesajen.

Sistem religi dalam Legenda Sungai Naga dapat dilihat seperti data (9) dan (10) di bawah ini.

(9) ... "Ya Tuhan, berikan petunjukMu untuk menghadapi bencana yang akan menimpa desa kami! Ya Tuhan, berikan pertolongan dan perlindungan kepada kami!" Ia senantiasa berdoa kepada Tuhan memohon pertolongan dan perlindungan dari bencana yang akan menimpa desanya.

(10) Gerdu bertapa dengan tujuan mencari petunjuk untuk mengatasi bencana yang akan terjadi. Dia bertapa selama tujuh hari tujuh malam dengan berbagai hambatan dan cobaan.

Berdasarkan kutipan (9) dan (10), dapat ditemukan bahwa tokoh utama merupakan seorang yang religius. Dia berdoa, berserah diri, dan memohon pertolongan kepada Tuhan Yang Maha Esa.

Nuansa gaib dan tak masuk akal juga dapat ditemukan dalam penggalan seperti di bawah ini.

(11) Lubang gua tersebut dapat mengantarkan orang sakti ke tempat-tempat yang dituju misalnya ke kota, ke negara lain, dan bahkan ke alam gaib dengan mantra dan kekuatan yang dimilikinya.Setelah ular besar itu melintas, tongkat yang ditancapkan tumbuh menjadi pohon besar, pohon preh namanya.Akhirnya, muncullah mata air di tempat Tongkat Sakti itu tertancap.

Hal-hal mistis di luar nalar pada data (11) merupakan suatu keyakinan masyarakat Jawa, khususnya Ngadiluwih yang telah tertanam dalam kehidupan bermasyarakat. Lubang gua dapat tembus ke berbagai daerah, tongkat yang ditancapkan dapat menjadi pohon besar, dan mata air yang muncul disebabkan oleh tongkat.

Keyakinan masyarakat akan adanya makhluk gaib merupakan bagian dari sistem religi. Hal tersebut ada dalam Legenda Sungai Naga seperti kutipan di bawah ini.

(12) Tidak mudah untuk mengambil tongkat sakti yang ada di mata air Serdudo. Ger$\mathrm{du}$ harus dapat mengalahkan danyang atau penunggu mata air tersebut yang berasal dari kalangan makhluk halus.

(13) Setelah pengambilan tongkat, Gerdu mendapat bisikan dari penunggu mata air Serdudo. Bisikannya agar tongkat itu direndam selama tujuh hari tujuh malam di Tempuran, yakni tempat bertemunya dua aliran sungai. 
(14) ... Tongkat itu diletakkan di dalam peti dan ditutupi kain putih dengan bunga tujuh rupa serta wewangian.

Kutipan legenda (12), (13), dan (14) menunjukkan adanya keyakinan terhadap hal gaib, benda-benda pusaka, dan kejadian mistis lainnya. Hal ini tampak dari Gerdu yang berkelahi dengan penunggu mata air yang berasal dari golongan makhluk halus dan pengagungan terhadap sebuah tongkat yang harus diperlakukan sebagai benda keramat.

\section{Nilai-Nilai Pendidikan Karakter}

Legenda Sungai Naga dapat dijadikan bahan ajar di SD, SLTP, dan SLTA khususnya dalam mata pelajaran Bahasa Indonesia. $\mathrm{Hal}$ itu dikarenakan dalam cerita Legenda Sungai Naga mengandung nilai-nilai pendidikan karakter. Nilai pendidikan karakter yang terdapat pada Legenda Sungai Naga yaitu nilai kerja keras, religius,dan peduli lingkungan.

\section{Nilai Karakter Kerja Keras}

Nilai karakter kerja keras dapat dilihat pada tindakan dan usaha Gerdu dalam mencari cara untuk menghalau bencana terjangan ular naga.

(15) "Dia bertapa selama tujuh hari tujuh malam dengan berbagai hambatan dan cobaan."

Tindakan Gerdu dengan menaklukkan hambatan dan cobaan selama dia bertapa merupakan sikap kerja keras yang dimilikinya (data 14). Selama tujuh hari dia diganggu oleh penunggu goa agar pertapaannya gagal. Melalui sikapnya yang tangguh dia dapat melewati segala rintangan yang ada.

Nilai karakter kerja keras selanjutnya ditunjukkan ketika dia melawan penunggu mata air tempat Tongkat Sakti berada. Bertarung mati-matian untuk mengambilnya.

(16) "Dia mengerahkan seluruh kekuatan dan kesaktiannya untuk melawan penunggu mata air."

Keberhasilan Gerdu dalam mengatasi bencana tidaklah instan. Dia harus melewati berbagai jalan yang berliku (data 16). Pertama, dia harus bertapa untuk mencari solusi.
Kedua, dia harus mendapatkan Tongkat Sakti, alat yang digunakan untuk menangkal bencana. Ketiga, dia harus menancapkan Tongkat Sakti pada tempat yang sudah ditentukan dan pada waktu yang sudah ditentukan pula.

\section{Nilai Karakter Religius}

Nilaikarakter religius seperti yang sudah tertera pada pembahasan sistem religi di atas. Manusia hanyalah makhluk yang kecil dan lemah. Untuk itu, sehebat apapun manusia tidak boleh sombong dan harus senantiasa memohon pertolongan kepada Tuhan Yang Maha Esa. Senantiasa beribadah dan memuji kepada Tuhan Yang Maha Esa.

(17) "Ya Tuhan, berikan petunjuk-Mu untuk menghadapi bencana yang akan menimpa desa kami! Ya Tuhan, berikan pertolongan dan perlindungan kepada kami!" Ia senantiasa berdoa kepada Tuhan me mohon pertolongan dan perlindungan dari bencana yang akan menimpa desanya.

Kutipan data (17) menunjukkkan bahwa Gerdu merupakan pemuda yang religius dan mempunyai akhlak yang baik. Hal tersebut sebagaimana terlihat saat dia berdoa, meminta pertolongan, meminta perlindungan, dan memohon petunjuk kepada Tuhan. Beribadah dan berusaha merupakan kunci dari keberhasilan terhadap suatu hal.

\section{Nilai Karakter Peduli Lingkungan}

Nilai karakter peduli lingkungan ditunjukkan dalam tindakan Gerdu dan saudaranya. Mereka tak ingin kampung tempat tinggalnya rusak poranda akibat bencana.

(18) "Gerdu tidak sendirian, ia ditemani ibu, ayah, kakek, paman, bibi, dan temannya. Bagaimana ini Gerdu? Apa yang harus kita lakukan? tanya Kakek."

Lingkungan sebagai tempat tinggal makhluk hidup harus dijaga untuk keberlangsungan kehidupan seluruh makhluk hidup. Kutipan data (18) menujukkan sikap peduli.

(19) "Hai Gerdu, berikan jalan untukku! Sebentar lagi aku akan turun melewati desamu" ucapnya. "Jika benar kamu akan turun mele wati desaku, turunlah ta- 
pi jangan sampai menabrak dan merusak desaku!"“ ucap Gerdu.

(20) "Jika u lar besar itu turun melewati Ngadiluwih pasti bencana banjir bandang akan terjadi," pikirnya.

Sikap kepedulian Gerdu terhadap lingkungan, desa, dan masyarakatnya terlihat pada kutipan (19) dan (20). Dia berucap kepada ular besar agar tidak menabrak dan merusak desanya. Sikap pedulinya juga menjadi beban pikiran hingga ia memikirkan bagaimana musibah yang terjadi jika ular besar menerjang desanya.

\section{Pembahasan}

Legenda diciptakan oleh manusia dengan tujuan untuk memahami peristiwa yang berkaitan dengan alam. Berdasarkan hasil penelitian di atas, asal-usul nama Sungai Naga sangat berkaitan dengan peristiwa alam yang dahulu pernah terjadi di lokasi tersebut. Dinamakan Sungai Naga karena diketahui ada ular besar berjenis naga, masyarakat menyebutnya Baru Klinting, melintas di sungai Dusun Ngadiluwih. Berkat seorang pemuda yang bernama Gerdu, akhirnya ular naga dapat melintasi sungai di Ngadiluw ih tanpa menyebabkan kerusakan perkampungan penduduk. Banyak tempat-tempat di Indonesia yang penamaannya berkaitan dengan alam atau peristiwa yang dahulu pernah terjadi. Misalnya, nama Lamongan, dalam sejarahnya diketahui tidak lepas dari riwayat Kasunanan Giri dan sosok yang bernama Hadi, Mbah Lamong.

Legenda Sungai Naga tidak dapat dilepaskan dari adat istiadat dan kebudayaan Jawa. Hal tersebut dikarenakan lokasinya yang berada dalam tataran kehidupan Suku Jawa. Berdasarkan hasil pene litian di atas, dapat diketahui bahwa dalam Legenda Sungai Naga terdapat tiga unsur kebudayaan yaitu sistem pengetahuan, sistem peralatan hidup dan teknologi, dan sistem religi. Pengetahuan dan pola pikir masyarakat yang menganggap suatu hal luar biasa patut diabadikan menjadikan terjadinya proses penamaan suatu tempat. Adanya ular besar yang melintas di sungai sebagaimana dalam legenda ini dijadikan nama untuk sebuah sungai yang dilaluinya. Legenda Sungai Naga yang notabene berada di wilayah pedesaan dengan masyarakat yang mayoritas penduduknya bertani dan berburu serta ber- teknologi tradisional, menjadikan peristiwa dalam cerita menggunakan alat-alat tradisional pula. Tongkat Sakti, sebuah alat tradisional dari kayu yang dapat dijadikan sebagai senjata. Masyarakat Jawa adalah masyarakat religi. Hal tersebut juga tampak dalam hasil penelitian ini bahwa masyarakat percaya akan adanya Tuhan, makhluk gaib, dan barangbarang yang mempunyai kekuatan supranatural.

Hasil penelitian pada Legenda Sungai Naga juga ditemukan nilai-nilai pendidikan karakter. Ditemukan tiga nilai pendidikan karakter, yaitu nilai karakter kerja keras, nilai karakter religius, dan nilai karakter peduli lingkungan. Ketiga, nilai pendidikan karakter tersebut merupakan identifikasi dari tiga nilai pembentuk karakter yang ada dalam satuan pendidikan. Pentingnya penerapan pendidikan karakter dalam dunia pendidikan harus didukung oleh bahan ajar yang sesuai. Mata pelajaran Bahasa Indonesia SMP/MTs kelas VII Kurikulum 2013 terdapat kompetensi dasar menggali legenda atau fabel dari daerah setempat. Oleh karena itu, harus dipilih ceritacerita yang memiliki nilai pendidikan karakter yang cocok digunakan di dunia pendidikan.Termuatnya nilai-nilai pendidikan karakter dalam Legenda Sungai Naga dapat digunakan sebagai pendukung bahan pembelajaran Bahasa Indonesia pada jenjang SD, SLTP, dan SLTA. Hasil penelitian Rapi Tang, Jufri, dan Sultan (2015) menunjukkan bahwa bahan ajar apresiasi sastra yang dikembangkan berbasis wacana budaya dapat meningkatkan prestasi belajar peserta didik.

Pembelajaran Bahasa Indonesia dapat memberikan konstribusi lebih pada kearifan lokal dan pendidikan karakter. Materi Kurikulum 2013 memberikan keleluasaan peserta didik untuk menggali informasi cerita rakyat (legenda, mitos, dan fabel) yang ada di sekitar lingkungan peserta didik tinggal. Hal ini memberikan dampak positif terhadap keberlangsungan cerita rakyat di daerahnya sehingga dapat secara turun-temurun diketahui oleh para generasinya. Selain itu, di dalam cerita rakyat juga terdapat nilai-nilai pendidikan karakter yang dapat diteladani peserta didik.

Widianti, Nuryatin, dan Indiatmoko (2017) menemukan 8 nilai moral dalam cerita babad Cirebon, yakni nilai tanggung jawab, kejujuran, toleransi, penghormatan, kerja keras, kasih sayang, religius, dan tolong-meno- 
long. Komariah (2018) dalam pene litiannya menemukan nilai karakter dalam cerita Rakyat Kuningan mencakup nilai-nilai utama yang secara khusus didistribusikan ke dalam mata pelajaran Bahasa Indonesia, yaitu (1) berpikir logis, (2) kritis, (3) kreatif dan inovatif, (4) percaya diri, (5) bertanggung jawab, (6) ingin tahu, (7) santun, dan (8) nasionalis. Selanjutnya, cerita Rakyat Kuningan dikembangkan menjadi bahan ajar yang dapat digunakan pembelajaran di SMP. Sama halnya dengan cerita babad Cirebon dan cerita Rakyat Kuningan, dalam Legenda Sungai Naga juga ditemukan nilai karakter kerja keras, nilai karakter religius, dan nilai karakter peduli lingkungan. Akan tetapi, da lam penelitian pada Legenda Sungai Naga juga diteliti unsur kebudayaan yang ada di dalamnya.

Kebudayaan lahir dari masyarakat dan masyarakat hidup dalam suatu budaya. Setiap daerah memiliki keunikan tersendiri. Miharja (2016) dalam penelitiannya tentang wujud kebudayaan masyarakat adat Cikondang menemukan empat hasil, yaitu pertama, masyarakat yang bergantung pada alam. Kedua, konsep pandangan hidupnya silih asih; silih asah; dan silih asuh. Ketiga, wujud aktifitas masyarakat yang rutin dilakukan tiap tahun yakni wuku taun, tradisi ngaruat hajat, tradisi ngaruat lembur, tradisi ngaruat solokan, bumi tradisi pertanian, dan tradisi hajat paralon. Keempat, hutan keramat dan rumah adat merupakan wujud kebudayaan dalam bentuk artefak. Senada dengan penelitian tersebut, penelitian ini menemukan beragam nilai budaya dan nilai pendidikan yang relevan untuk pengembangan pendidikan karakter. Oleh karena itu, karya sastra lokal yang kaya nilainilai layak digunakan sebagai sumber bahan ajar.

Penelitian cerita rakyat Enyeng di desa Cipancar, Sumedang Selatan yang dilakukan oleh Sukmana (2018) ditemukan tiga aspek sosial budaya dalam cerita rakyat tersebut. Aspek sosial budaya tersebut yaitu budaya, pedesaan, dan ekonomi. Sama halnya dengan penelitian ini, Sukmana juga menganalis is cerita rakyat yang dapat digunakan untuk pem-

\section{DAFTAR PUSTAKA}

Azhar, N. I. 2016. Ledenskap Masyarakat Bangkalan dan Unsur-Unsur Pembentuknya. Ata- belajaran di sekolah. Hasil penelitian ini memberikan perspektif tentang kandungan nilai budaya dalam karya sastra.

\section{SIMPULAN}

Berdasarkan hasil analisis dan pembahasan di atas, dapat ditarik simpulan bahwa sebuah legenda diciptakan oleh manusia dengan tujuan untuk memahami peristiwa yang berkaitan dengan alam. Hal ini tampak dalam kisah Gerdu dan Ular Naga Baru Klinting yang merupakan legenda mengenai asal-usul Sungai Naga. Dinamakan Sungai Naga karena diketahui bahwa ular yang melintas di sungai tersebut merupakan Ular Naga. Muncul mata air di tempat penancapan tongkat yang dijadikan benteng penyelamat dari terjangan ular tersebut sehingga aliran sungai dari mata air tersebut diberi nama Sungai Naga. Pada Legenda Sungai Naga juga ditemukan unsurunsur kebudayaan. Unsur kebudayaan yang ada dalam cerita tersebut ada tiga yaitu sistem pengetahuan, sistem peralatan hidup dan teknologi, dan sistem religi. Ketaatan tokoh utama kepada Tuhan Yang Maha Esa dan keyakinan masyarakat kepada hal-hal gaib serta kepada kekuatan supranatural merupakan unsur religi yang ditemukan dalam cerita.

Legenda Sungai Naga juga mengandung nilai pendidikan karakter sehingga cerita tersebut dapat digunakan sebagai bahan ajar Bahasa Indonesia di SD, SLTP, dan SLTA. Nilai pendidikan karakter yang terdapat pada Legenda Sungai Naga, yaitu nilai karakter kerja keras, nilai karakter religius, dan nilai karakter peduli lingkungan.

\section{UCAPAN TERIMA KASIH}

Ucapan terima kasih diberikan kepada seluruh narasumber yang telah bersedia diwawancarai guna mendapatkan informasi. Selanjutnya, ucapan terima kasih diberikan pula kepada mitra bestari (reviewers) yang telah memberikan saran, kritik, dan rekomendasi perbaikan artikel ini.

visme: Jurnal Ilmiah Kajian Sastra, 1 (2): 192-205. 
Camalia, M. 2015. Toponimi Kabupaten Lamongan (Kajian Antropologi Linguistik). Parole: Journal of Linguistik and Education, 5(1): 74-83.

Danandjaja, J. 2013. Folklor Indonesia Ilmu Gosip dan Dongeng. Jakarta: Graffiti Press.

Kemendiknas. 2011. Panduan Pelaksanaan Pendidikan Karakter. Jakarta: Kementerian Pendidikan.

Kesuma, D. 2011. Pendidikan Karakter Kajian Teori dan Praktik di Sekolah. Bandung: PT Remaja Rosdakarya.

Koentjaraningrat. 2015. Pengantar Ilmu Antropologi. Jakarta: PT Rineka Cipta.

Komariah, Y. 2018. Pengembangan Bahan Ajar Cerita Rakyat Kuningan Terintegrasi Nilai Karakter dalam Pembelajaran Apresiasi Sas tra di SMP. Deiksis, 5(1)100-110.

Kramsch, C. 2001. Language and Culture. New York: Oxford University Press.

Lee, M. A. 2013. The Dragon: The Principle of Cosmos. Journal of Symbols \& Sandplay Therapy, 4(2):70-76.

Mardiana, W. 2013. The Sapir-Whorf Hypotesis and Toponomy Study: Place Naming Using Javanese Language. Jakarta: Universitas Katolik Atmajaya.

Miharja, D. 2016. Wujud Kebudayaan Masyarakat Adat Cikondang dalam Melestarikan Lingkungan. Religios: Jurnal Agama dan Lintas Budaya, 1(1): 52-61.

Musfiroh, T. 2008. Memilih, Menyusun, dan Menyajikan Cerita untuk Anak Usia Dini. Yogyakarta: Tiara Wacana.
Nurgiyantoro, B. 2013. Sastra Anak: Pengantar Pemahaman Dunia Anak. Yogyakarta: Gadjah Mada University Press.

Permendikbud. 2016. Peraturan Menteri Pendidikan dan Kebudayaan Republik Indonesia Nomor 24 Tahun 2016 tentang Kompetensi Inti dan Kompetensi Dasar Pelajaran pada Kurikulum 2013 pada Pendidikan Dasar dan Pendidikan Menengah. Jakarta: Kementerian Pendidikan dan Kebudayaan.

Rais, J., dkk. 2008. Toponimi Indonesia. Jakarta: Pradnya Paramita.

Rapi Tang, M., Jufri, Sultan. 2015. Pengembangan Bahan Ajar Cerita Fiksi Berbasis Wacana Budaya di Sekolah Dasar. Pendidikan dan Pembelajaran, 22(2):169-175.

Samani, M., dan Hariyanto. 2013. Konsep dan Model Pendidikan Karakter. Bandung: PT Remaja Rosdakarya.

Sugiarto, E. 2015. Mengenal Sastra Lama. Yogyakarta: CV Andi Offset.

Sugiyono. 2010. Metode Penelitian Pendidikan Pendekatan Kuantitatif, Kualitatif, dan $R \& D$. Bandung: Alfabeta.

Sukmana, E. 2018. Aspek Sosial Budaya dalam Cerita Rakyat Enyeng di Desa Cipancar. Deiksis, 5(1): 18-23.

Widianti, N., Nuryatin, A., dan Indiatmoko, B. 2017. Nilai Moral dalam Cerita Babad Cirebon: Berdasarkan Penceritaan di Keraton Kanoman. Journal Indonesian Language Education and Literature, 3(1): 24-31. 